\title{
Nitrate Bioreduction in Redox-Variable Low Permeability Sediments
}

\author{
Sen Yan ${ }^{1,2}$, Yuanyuan $\mathrm{Liu}^{2}$, Chongxuan $\mathrm{Liu}^{1,2^{*}}$, Liang Shi ${ }^{2}$ Jianying Shang ${ }^{2}$, Huimei \\ Shan $^{1,2}$, John Zachara ${ }^{2}$, Jim Fredrickson ${ }^{2}$, David Kennedy ${ }^{2}$, Charles T. Resch ${ }^{2}$, \\ Christopher Thompson ${ }^{2}$, and Sarah Fansler ${ }^{2}$ \\ ${ }^{1}$ China University of Geosciences, Wuhan, 430074, China \\ ${ }^{2}$ Pacific Northwest National Laboratory, Richland, WA 99354, USA
}

A revised manuscript submitted to Science of the Total Environment

August, 2015

* Corresponding author:

E-mail: chongxuan.liu@pnnl.gov.

Tel: 1-509- 371-6880, Fax: 1-509- 371-6354;

Pacific Northwest National Laboratory, PO Box 999, MSIN: K8-96, Richland, WA 99354, USA

C 2015. This manuscript version is made available under the Elsevier user license http://www.elsevier.com/open-access/userlicense/1.0/ 


\begin{abstract}
Low permeability zone (LPZ) can play an important role as a sink or secondary source in contaminant transport in groundwater system. This study investigated the rate and end product of nitrate bioreduction in LPZ sediments. The sediments were from U.S. Department of Energy's Hanford Site, where nitrate is a groundwater contaminant as a by-product of radionuclide waste discharges. The LPZ at the Hanford site consists of two layers with an oxidized layer on top and reduced layer below. The oxidized layer is directly in contact with the overlying contaminated aquifer, while the reduced layer in contact with an uncontaminated aquifer below. The experimental results showed that nitrate bioreduction rate and endproduct differed significantly in the sediments. The bioreduction rate in the oxidized sediment was significantly faster than that in the reduced one. A significant amount of $\mathrm{N}_{2} \mathrm{O}$ was accumulated in the reduced sediment; while in the oxidized sediment, $\mathrm{N}_{2} \mathrm{O}$ was further reduced to $\mathrm{N}_{2}$. RT-PCR analysis revealed that nos $Z$, the gene that codes for $\mathrm{N}_{2} \mathrm{O}$ reductase, was below detection limit in the reduced sediment. Batch experiments and kinetic modeling were performed to provide insights into the role of organic carbon bioavailability, biomass growth, and competition between nitrate and its reducing products for electrons from electron donors. The results revealed it is important to consider sediment redox conditions and functional genes in understanding and modeling nitrate bioreduction in subsurface sediments. The results also implied that LPZ sediments can be important sink of nitrate and a potential secondary source of $\mathrm{N}_{2} \mathrm{O}$ as a nitrate bioreduction product in groundwater.
\end{abstract}

Keywords: Nitrate bioreduction; Low permeability zone; Subsurface redox transitional sediments; Nitrous oxide; Organic carbon speciation; Kinetic model 


\section{Introduction}

Nitrate is a major contaminant in groundwater worldwide (Rivett et al., 2008). Nitrate attenuation in groundwater is primarily controlled by biogeochemical processes that reduce nitrate $\left(\mathrm{NO}_{3}{ }^{-}\right)$to gaseous nitrous oxide $\left(\mathrm{N}_{2} \mathrm{O}\right)$, dinitrogen $\left(\mathrm{N}_{2}\right)$, or ammonium $\left(\mathrm{NH}_{4}{ }^{+}\right)$(Zumft, 1997). In aquatic systems, nitrate bioreduction predominately occurs in sediments (Laverman et al., 2006), removing nitrate entering rivers (Laverman et al., 2010) and oceans (Ward, 2013). Extensive research has been performed to understand various processes and factors controlling the rate, extent, and intermediate and end products of nitrate bioreduction in environments (Rivett et al., 2008; Seitzinger et al., 2006). The rate and extent of nitrate bioreduction are affected by dissolved oxygen concentration (Rassamee et al., 2011), organic carbon speciation and contents (Babbin et al., 2014; Lu and Chandran, 2010) and denitrifier abundance and gene expression (Zhang et al., 2014). Other factors including nitrate concentration, nutrient availability, $\mathrm{pH}$, and temperature can also affect the rate and intermediate products of nitrate bioreduction (Firestone et al., 1980; Pan et al., 2012; Rivett et al., 2008). In reduced sediments, the presence of sulfide and Fe(II) species may stimulate nitrate bioreduction via sulfide or Fe(II) oxidation (Vaclavkova et al., 2014; Zhang et al., 2009). A recent study found that the end product of nitrate bioreduction in oligotrophic lake sediments is largely determined by sediment redox conditions (Small et al., 2014). However, the mechanisms and process-level understanding on the effect of redox conditions on nitrate bioreduction rate in the subsurface and its relationship with microbial functional gene are not well-understood.

Nitrate contaminant in the subsurface can be attenuated via denitrification (Rivett et al., 2008), which refers to an assemblage of nitrate, nitrite, $\mathrm{NO}$ and $\mathrm{N}_{2} \mathrm{O}$ respiration in the absence of oxygen (Zumft, 1997). $\mathrm{N}_{2} \mathrm{O}$ can be the end product of incomplete denitrification (Zumft, 1997). Various factors have been identified that lead to $\mathrm{N}_{2} \mathrm{O}$ emission as the end product of nitrate bioreduction. The presence of trace oxygen, minor free nitrous acid species, low $\mathrm{pH}$, high initial nitrate, and nitrite concentrations can individually or collectively inhibit $\mathrm{N}_{2} \mathrm{O}$ reduction to $\mathrm{N}_{2}$ (Firestone et al., 1980; Kampschreur et al., 2009; Laverman et al., 2010; Pan et al., 2012; Rassamee et al., 2011). On the other hand, high organic carbon concentration, low nitrate and nitrite concentration, and long duration of anaerobiosis favor $\mathrm{N}_{2}$ as the end product (Butterbach-Bahl et al., 2013; Kampschreur et al., 2009; Weymann et al., 2010). These findings were primarily derived from studies in wastewater treatment systems, agricultural soils, streams and rivers. Limited studies indicated that groundwater systems are also important sources or sinks of $\mathrm{N}_{2} \mathrm{O}$ 
(Ronen et al., 1988; Weymann et al., 2010). The relative importance of $\mathrm{N}_{2} \mathrm{O}$ production in groundwater to land/surface $\mathrm{N}_{2} \mathrm{O}$ flux, the mechanisms leading to $\mathrm{N}_{2} \mathrm{O}$ accumulation in groundwater, and reactive transport of $\mathrm{N}_{2} \mathrm{O}$ in sediment-groundwater system have not been well studied.

Low permeability zones (LPZs) are important subsurface units that can retard and attenuate contaminant migration in groundwater (Arighi et al., 2005; Robertson et al., 1996; Liu and Ball, 2002). Nitrate bioreduction in LPZ sediments is, however, an under-studied area (Rivett et al., 2008). Limited studies indicate that LPZ sediments may strongly affect the fate and transformation of nitrate in groundwater (Lin et al., 2012a; Lee et al., 2012). These studies revealed that nitrate bioreduction primarily resulted from heterotrophic activities, and the effect of lithoautotrophic Fe(II)- and sulfide- oxidizing microorganisms (such as E. shelobolina) was negligible (PercakDennett and Roden, 2014). A diffusion-based reactive transport model had been established by incorporating nitrate bioreduction kinetics that provided important insights into nitrate migration and attenuation in LPZ (Percak-Dennett and Roden, 2014). These previous studies in the LPZ sediments, however, focused on the loss of nitrate without considering the reduction kinetics of nitrite and $\mathrm{N}_{2} \mathrm{O}$. Field monitoring at the U.S. Department of Energy's Hanford site, however, found the accumulation of $\mathrm{N}_{2} \mathrm{O}$ in groundwater in LPZ and nearby aquifer zones, indicating that it is important to consider the bioreduction of nitrate and its reduction products. In addition, the redox potential of LPZ sediments often varies as a function of distance from nearby aquifer. Consequently, the objective of this study is to investigate the bioreduction kinetics of nitrate and its reduction products in LPZ sediments with different redox potentials. Batch experiments using both the oxidized and reduced sediments were performed to characterize the bioreduction rates of nitrate and its reduction products, and to determine the end product of nitrate bioreduction (e.g., $\mathrm{N}_{2} \mathrm{O}, \mathrm{N}_{2}$, or $\mathrm{NH}_{4}^{+}$). Real-time polymerase chain reaction (RT-PCR) analysis was performed to investigate the mechanisms controlling $\mathrm{N}_{2} \mathrm{O}$ or $\mathrm{N}_{2}$ as the end product of nitrate bioreduction. Controlled experiments and kinetic modeling were performed to provide insights into the effect of organic carbon content and speciation, microbial growth, and various model parameters on nitrate bioreduction. The results provided important insights into the effect of sediment redox state, indigenous organic carbon, and long-term adaption of microbial community on the rate and end product of nitrate bioreduction in LPZ sediments as subsurface units.

\section{Materials and methods}




\subsection{Sediments}

The sediments used in this study were obtained from a LPZ at the U.S. Hanford 300 Area Integrated Field Research Challenge (IFRC) site (http://ifchanford.pnl.gov), where nitrate is a contaminant in the overlying aquifer (Bjornstad et al., 2009). The LPZ consists of an upper layer of yellow-brown Miocene-Pliocene-aged lacustrine fine-grained oxidized sediment (OS) and a lower layer of dark grey to black Miocene-Pliocene-aged lacustrine finegrained reduced sediment (RS). The LPZ separates the overlying aquifer formation from the underlying Ringold formation (Lin et al., 2012b). The OS and RS were collected aseptically from ca. 18.0-18.3 m depth and ca. 18.6$18.9 \mathrm{~m}$ depth of core C-6209 recovered during drilling. The sediment core was stored in a $-80^{\circ} \mathrm{C}$ freezer and thawed at $4{ }^{\circ} \mathrm{C}$ before use for the experiments. The geochemical and microbial community properties in the sediments have been characterized previously as described elsewhere (Lee et al., 2012; Lin et al., 2012a, 2012b; Percak-Dennett and Roden, 2014; Peretyazhko et al., 2012). Important properties from the previous characterization and the present study are summarized in Table 1. Briefly, the RS contains over 9 times of organic carbon and HCl-extractable Fe(II) than the OS. The biomass and microbial diversity in the RS are much lower than those in the OS. The biomass numbers determined by most probable number culture method (Lin et al., 2012a) show that denitrifiers, aerobes, and fermenters reside in both OS and RS with higher abundance in the OS. Sulfate reducer population is similar in the OS and RS. 
Table 1 Biogeochemical properties in the oxidized sediment (OS) and reduced sediment (RS).

\begin{tabular}{|c|c|c|c|c|c|c|c|c|c|c|c|c|c|c|c|c|}
\hline \multirow{2}{*}{$\begin{array}{l}\text { sedim } \\
\text { ent }\end{array}$} & \multirow{2}{*}{$\begin{array}{c}\mathrm{C}_{\text {or }} \\
\mathrm{g} \\
(\% \\
) \\
\end{array}$} & \multirow{2}{*}{$\begin{array}{c}\mathrm{Fe}(\mathrm{II}) \\
\mathrm{HCl}^{\mathrm{a}} \\
(\mu \mathrm{mol} \\
/ \mathrm{g}) \\
\end{array}$} & \multirow{2}{*}{$\begin{array}{c}\underset{\substack{\text { pyritic } \\
\text { a }}}{ } \\
(\mu \mathrm{mol} \\
/ \mathrm{g}) \\
\end{array}$} & \multirow{2}{*}{$\begin{array}{c}\mathrm{Fe}_{\text {total }} \\
\mathrm{a} \\
\left(\begin{array}{c}\mu \mathrm{mol} \\
/ \mathrm{g})\end{array}\right. \\
\end{array}$} & \multirow[t]{2}{*}{$\begin{array}{c}\text { denitrifi } \\
\text { ers }^{\mathrm{b}}\end{array}$} & \multirow[t]{2}{*}{$\begin{array}{c}\mathrm{Fe} \\
\text { reducer } \\
\mathrm{s}^{\mathrm{b}} \\
\end{array}$} & \multirow[t]{2}{*}{$\begin{array}{c}\text { aerobe } \\
\mathrm{s}^{\mathrm{b}}\end{array}$} & \multirow[t]{2}{*}{$\begin{array}{c}\text { ferment } \\
\text { ers }^{b}\end{array}$} & \multirow{2}{*}{ 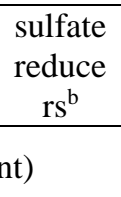 } & \multirow{2}{*}{$\begin{array}{l}\mathrm{OT} \\
\mathrm{Us}^{\mathrm{c}}\end{array}$} & \multicolumn{3}{|c|}{$\begin{array}{c}16 \mathrm{~S} \\
\text { rRNA }\end{array}$} & \multicolumn{2}{|r|}{ nos $Z$} & \\
\hline & & & & & & & & & & & & & pies per gran & $\overline{\mathrm{sed}}$ & ment) & \\
\hline \multirow{2}{*}{ OS } & 0. & $9.4 \pm 0$ & nd & 671 & $2.67 \mathrm{E}+$ & $1.71 \mathrm{E}+$ & $4.60 \mathrm{E}$ & $4.60 \mathrm{E}+$ & $1.71 \mathrm{E}$ & \multirow[t]{2}{*}{325} & $\mathrm{n}$ & $43195 \pm 41$ & $112662 \pm 16$ & $\mathrm{n}$ & $3215 \pm 7$ & $34536 \pm 60$ \\
\hline & 05 & 4 & & & 03 & 03 & +03 & 03 & +03 & & $\mathrm{~d}^{\mathrm{d}}$ & $70^{\mathrm{e}}$ & $086^{\mathrm{f}}$ & $\mathrm{d}^{\mathrm{d}}$ & $75^{\mathrm{e}}$ & $78 \mathrm{f}$ \\
\hline \multirow[b]{2}{*}{$\mathrm{RS}$} & 0. & $85.1 \pm$ & 86.6 & \multirow[b]{2}{*}{679} & $1.73 \mathrm{E}+$ & \multirow[b]{2}{*}{ nd } & $1.73 \mathrm{E}$ & $1.95 \mathrm{E}+$ & $1.73 \mathrm{E}$ & \multirow[b]{2}{*}{50} & $\mathrm{n}$ & \multirow[b]{2}{*}{$\mathrm{nd}^{\mathrm{e}}$} & \multirow[b]{2}{*}{$1509 \pm 1173^{\mathrm{f}}$} & $\mathrm{n}$ & \multirow[b]{2}{*}{$\mathrm{nd}^{\mathrm{e}}$} & \multirow[b]{2}{*}{$n d^{f}$} \\
\hline & 51 & 0.5 & & & 03 & & +02 & 02 & +03 & & $\mathrm{~d}^{\mathrm{d}}$ & & & $\mathrm{d}^{\mathrm{d}}$ & & \\
\hline
\end{tabular}

${ }^{a}$ the $\mathrm{Fe}(\mathrm{II})_{\mathrm{HCl}}$ and $\mathrm{Fe}_{\text {total }}$ data were adopted from Peretyazhko et al. (2012); ${ }^{\mathrm{b}}$ from Lin et al. (2012a); ${ }^{\mathrm{c}}$ OTUs: operational taxonomic units at the $97 \%$ identity level (from Lin et al. 2012b); ${ }^{d}$ in fresh sediments before incubation; ${ }^{\text {in }}$ incubated sediments without organic carbon spike; ${ }^{\text {in }}$ incubated sediments with organic carbon spike. ${ }^{\mathrm{d}-\mathrm{f}}$ The errors of nos $Z$ and $16 \mathrm{~S}$ rRNA data are standard deviation of three RT-PCR measurements. 


\subsection{Nitrate reduction experiments}

\subsubsection{Batch Experiments}

Batch experiments were performed in duplicates to determine nitrate bioreduction rate and to identify factors controlling the rate and end product of nitrate bioreduction in the sediments. Sediment suspensions were prepared in $160 \mathrm{ml}$ glass bottles, by mixing a known weight (from 10 to $40 \mathrm{~g}$ ) of sediment with $50 \mathrm{~mL}$ anoxic filter-sterilized synthetic groundwater (SGW), which mimicked Hanford 300 area groundwater chemical composition (Liu et al., 2013). The glass bottles were sealed with butyl rubber stoppers and all preparations were made in an anoxic chamber, filled with $\mathrm{N}_{2}$ (Innovative Technology Inc.). A summary of the experimental conditions is provided in Table S1 in Supplementary Information (SI). Sediment/SGW ratio $(200,400$, or $800 \mathrm{~g} / \mathrm{L})$ and initial nitrate concentration $(0.46-2 \mathrm{mM})$ were varied to investigate the effects of sediment-associated initial biomass and organic carbon content, and nitrate concentration on the rate of nitrate bioreduction. In the reactors with sediment/SGW ratio at $200 \mathrm{~g} / \mathrm{L}$, a mixed organic carbon (OC) source $(0.9 \mathrm{mM}$ acetate, $0.6 \mathrm{mM}$ lactate, and $0.3 \mathrm{mM}$ glucose $)$ was spiked to evaluate the rate limitation of organic carbon. Control experiments were performed in duplicates by autoclaving the sediments at $120{ }^{\circ} \mathrm{C}$ for $30 \mathrm{~min}$ and for three times during three consecutive days to examine whether nitrate and nitrite could be reduced abiotically.

The sediment suspensions were incubated at room temperature on a reciprocal shaker operated at $300 \mathrm{rpm}$, within the anoxic chamber where oxygen levels were maintained below $0.1 \mathrm{ppm}$. Suspension was sampled periodically using $3 \mathrm{~mL}$ syringes fit with $18 \mathrm{G}$ needles. Pretests were performed to determine sampling frequency and timing. For each suspension sample, $0.25 \mathrm{~mL}$ subsample was mixed with $0.25 \mathrm{~mL} 40 \mathrm{mM}$ Ethylenediaminetetraacetic acid (EDTA) for Adenosine Triphosphate (ATP) analysis, and the remaining $2.75 \mathrm{~mL}$ subsample was filtered $(0.2 \mu \mathrm{m})$. Among the filtrate, $1.5 \mathrm{~mL}$ was used for analyzing $\mathrm{NO}_{3}{ }^{-}, \mathrm{NO}_{2}{ }^{-}, \mathrm{SO}_{4}{ }^{2-}$ and $\mathrm{NH}_{4}{ }^{+}$ concentrations, and $0.5 \mathrm{~mL}$ was acidified with $5 \mu \mathrm{L} 1.25 \mathrm{M} \mathrm{H}_{2} \mathrm{SO}_{4}$ for organic carbon analysis in the incubations with OC spike. At the end of kinetic experiments, the remaining suspensions were collected, frozen in liquid nitrogen, and stored at $-80{ }^{\circ} \mathrm{C}$ until DNA extraction. In the reactors spiked with $\mathrm{OC}, \mathrm{N}_{2} \mathrm{O}$ in the head space was sampled before aqueous sampling. To preserve headspace gas pressure, $1 \mathrm{~mL}$ of $\mathrm{N}_{2}$ was injected into the reactor using a $1 \mathrm{~mL}$ gas-tight syringe before $1 \mathrm{~mL}$ gas sample was taken from the headspace. The $1 \mathrm{~mL}$ gas sample was 
mixed with $7 \mathrm{~mL} \mathrm{~N} \mathrm{~N}_{2}$ in a sealed serum vial for $\mathrm{N}_{2} \mathrm{O}$ analysis. The resulting dilution of the headspace gas before taking samples was considered in calculating $\mathrm{N}_{2} \mathrm{O}$ concentrations. After the gas sampling, $3 \mathrm{~mL}$ of $\mathrm{N}_{2}$ was injected into the reactors before taking $3 \mathrm{~mL}$ suspension samples for aqueous phase analysis as described above.

\subsubsection{Sample analysis}

$\mathrm{NO}_{3}^{-}, \mathrm{NO}_{2}^{-}$, and $\mathrm{SO}_{4}{ }^{2-}$ concentrations in aqueous samples were determined using ion chromatograph (Dionex ICS-2000). The analysis was performed using isocratic 15 -min elution with $22 \mathrm{mM} \mathrm{KOH}$ eluent at $30^{\circ} \mathrm{C}$ at a flow rate of $1 \mathrm{~mL} \mathrm{~min}^{-1}$. A IonPac AG18 guard column and an IonPac AS18 separate column were used with an anion suppressor. Standards were made from Spex CertiPrep solution $(1,000 \mathrm{mg} / \mathrm{L}$ anion standards, Metuchen, NJ) with dilutions calibrated from 0.19 to $120 \mathrm{mg} / \mathrm{L}$ (except for nitrite, from 0.06 to $40 \mathrm{mg} / \mathrm{L}$ ). Aqueous $\mathrm{NH}_{4}{ }^{+}$concentrations were colorimetrically analyzed using the Nessler reagent (Streuli and Averell, 1970). The acetate, lactate and glucose concentrations in aqueous samples were determined by HPLC (Agilent 1100) with a $300 \mathrm{x} 7.8 \mathrm{~mm}$ Aminex HPX-87H column (Bio-Rad, Hercules, CA), a $0.008 \mathrm{~N} \mathrm{H}_{2} \mathrm{SO}_{4}$ mobile phase with a flow rate of $0.6 \mathrm{ml} / \mathrm{min}$ and variable wavelength detector (VWD) at $210 \mathrm{~nm}$ for acetate and lactate and refraction index detector (RID) for glucose. The linear ranges for acetate, lactate and glucose calibrated from $0.113 \mathrm{mM}$ to $0.9 \mathrm{mM}, 0.075 \mathrm{mM}$ to 0.6 $\mathrm{mM}$, and $0.038 \mathrm{mM}$ to $0.3 \mathrm{mM}$, respectively. We didn't measure dissolved organic carbon in the reactors without OC spike, since a few pretests using the same sediments found that the dissolved organic carbon was below detection limit. ATP concentration was measured using a luminometer following Promega's protocol (Stanley, 1989). Total organic carbon contents in the sediment samples were determined using Carbon analyzer (Shimadzu SSM-5000A). $\mathrm{N}_{2} \mathrm{O}$ concentrations in gas samples were determined using gas chromatograph (SRI 8610C Greenhouse Gas Monitor) equipped with a ${ }^{63} \mathrm{Ni}$ electron capture detector and a flame ionization detector. A 1-mL gas sample loop was used to inject samples onto the packed separation columns, which consisted of $2 \mathrm{~m}$ HaysepDand and $1 \mathrm{~m}$ Shincarbon joined with a $30 \mathrm{~cm}$ length of $1 / 8^{\prime \prime}$ outside diameter (OD) copper tubing. The $\mathrm{N}_{2}$ carrier gas pressure was set at $20 \mathrm{psi}$, and the column temperature was $100{ }^{\circ} \mathrm{C}$. The calibration range for $\mathrm{N}_{2} \mathrm{O}$ was from 0.017 to $4.266 \mathrm{ppm}$. For each analysis, $3 \mathrm{~mL}$ gas was injected into the $1 \mathrm{~mL}$ sample loop using $5 \mathrm{~mL}$ gas-tight syringe, which was flushed with high-purity $\mathrm{N}_{2}$ gas $(99.999 \%)$ twice before sampling. Blanks and standards were run regularly between samples. Standard recoveries ranged from $96 \%$ to $101 \%$ for $\mathrm{N}_{2} \mathrm{O}$ (mean $=99 \%$ ), indicating no contamination from atmospheric $\mathrm{N}_{2} \mathrm{O}$ during sampling and analysis. 
The DNA in the initial and incubated sediments (from 8 to $12 \mathrm{~g}$ ) were extracted following an established procedure (Lin et al., 2012a; Lin et al., 2012b). Briefly, the cells were lysed by bead-beating the sediments with $70{ }^{\circ} \mathrm{C}$ lysis buffer, sodium dodecyl sulfate, and casein solution for $10 \mathrm{~min}$, and heated in $70{ }^{\circ} \mathrm{C}$ in water bath for 20 min, and then centrifuged at 5,000 g for $10 \mathrm{~min}$. The supernatant containing DNA was collected and then mixed with a solution containing 1 part $3 \mathrm{M} \mathrm{Na}$-acetate and 7 parts bioreagent 2 -propanol (>99.5\%) to precipitate DNA. The mixture was centrifuged at $9,000 \mathrm{~g}$ for $60 \mathrm{~min}$ at $4{ }^{\circ} \mathrm{C}$, and the precipitates were collected. The DNA in the precipitates was first extracted using phenol:chloroform:isoamyl alcohol $(25: 24: 1)$, and then twice extracted using chloroform/isoamyl alcohol (24:1) and 2-propanol. The DNA was finally diluted in $100 \mu \mathrm{L}$ of $10 \mathrm{mM}$ tris(hydroxymethyl)aminomethane. The plasmid 16S rRNA and nosZ gene standards were prepared following an established protocol described elsewhere (Lin et al., 2012b). All the quantitative PCR reactions were performed with a StepOnePlus $^{\mathrm{TM}}$ real-time PCR system (Applied Biosystems Inc., Foster City, CA) programmed for 40 cycles. Power SYBR ${ }^{\circledR}$ green PCR master mix was used for all the samples assays, and 16S rRNA and nos $Z$ gene fragments were included in each run to establish standard curves. The primers $27 \mathrm{~F}$ and $1492 \mathrm{R}$, nos Z2-F and nos Z2- $R$ were used to amplify 16S rRNA and nosZ gene, respectively. After amplification, the melting curves of amplicons were analyzed to ensure that a single homogenous product was generated. The results herein were reported as the gene copies per gram sediment.

\subsection{Mathematical interpretation of observations}

The half-reactions involved in the nitrate bioreduction are provided in Table S2 in SI. The overall reactions for the nitrate and nitrite reduction can be assembled from the half-reactions:

1) Nitrate reduction to nitrite

$$
\begin{aligned}
\frac{1}{4} \mathrm{CH}_{2} \mathrm{O} & \left.+\left(\frac{1}{28}+\frac{13}{28} f_{e, \mathrm{NO}_{3}^{-} \rightarrow \mathrm{NO}_{2}^{-}}\right) \mathrm{NO}_{3}^{-}=\frac{1-f_{e, \mathrm{NO}-\mathrm{NO}}^{-}}{28} \mathrm{C}_{5} \mathrm{H}_{7} \mathrm{O}_{2} \mathrm{~N}+\frac{f_{e, \mathrm{NO}_{3}^{-} \rightarrow \mathrm{NO}_{2}^{-}} \mathrm{NO}_{2}^{-}+\frac{1}{8} \mathrm{HCO}_{3}^{-}}{2}\right) \mathrm{H}^{+}+\left(\frac{1}{56}+\frac{3}{28} f_{e, \mathrm{NO}_{3}^{-} \rightarrow \mathrm{NO}_{2}^{-}}\right) \mathrm{H}_{2} \mathrm{O}
\end{aligned}
$$

2) Nitrite reduction to dinitrogen 


$$
\begin{gathered}
\left.\frac{1}{4} \mathrm{CH}_{2} \mathrm{O}+\left(\frac{1}{26}+\frac{23}{78} f_{e, \mathrm{NO}_{2}^{-} \rightarrow N_{2}}\right) \mathrm{NO}_{2}^{-}=\frac{1-f_{e, \mathrm{NO}_{2}^{-} \rightarrow \mathrm{N}_{2}} \mathrm{C}_{5} \mathrm{H}_{7} \mathrm{O}_{2} \mathrm{~N}+\frac{f_{e, \mathrm{NO}_{2}^{-} \rightarrow \mathrm{N}_{2}}}{6} \mathrm{~N}_{2}+\frac{1}{8} \mathrm{HCO}_{3}^{-}}{26}\right) \mathrm{H}^{+}+\left(\frac{1}{104}+\frac{11}{39} f_{e, \mathrm{NO}_{2}^{-} \rightarrow \mathrm{N}_{2}}\right) \mathrm{H}_{2} \mathrm{O}
\end{gathered}
$$

where $f_{e}$ is the fraction of total number of electrons generated from organic carbon oxidation for the respiration (i.e., nitrate or nitrite reduction). Organic carbon speciation in the sediments was unknown and a molecular formula $\mathrm{CH}_{2} \mathrm{O}$ was used for modeling purpose to balance elemental composition in the reactions. Similarly, $\mathrm{C}_{5} \mathrm{H}_{7} \mathrm{O}_{2} \mathrm{~N}$ was used to describe elemental composition of biomass in the overall reactions. Reaction 1 is the overall reaction describing nitrate reduction to nitrite in coupling with organic carbon oxidation and biomass production. Reaction 2 is the overall reaction that merges intermediate reactions involving $\mathrm{N}_{2} \mathrm{O}$ (Table S2). These overall reactions have been used widely for mass and electron balance in modeling nitrate bioreduction in wastewater treatment engineering and agricultural systems (Ahn, 2006; Mastrocicco et al., 2011; Matějů et al., 1992; McCarty et al., 1969; Rittmann and McCarty, 2001; U.S. EPA, 1993). As described and discussed in the result section, however, $\mathrm{N}_{2} \mathrm{O}$, instead of $\mathrm{N}_{2}$ was the end product of nitrate bioreduction in the RS. Consequently, in this study, reaction 2 is replaced with the following reaction to balance overall mass and electron in describing nitrite reduction in the RS:

$$
\begin{aligned}
& \frac{1}{4} \mathrm{CH}_{2} \mathrm{O}+\left(\frac{1}{26}+\frac{6}{13} f_{e, \mathrm{NO}_{2}^{-} \rightarrow \mathrm{N}_{2} \mathrm{O}}\right) \mathrm{NO}_{2}^{-}=\frac{1-f_{e, \mathrm{NO}_{2}^{-} \rightarrow \mathrm{N}_{2} \mathrm{O}} \mathrm{C}_{5} \mathrm{H}_{7} \mathrm{O}_{2} \mathrm{~N}+\frac{f_{e, \mathrm{NO}_{2}^{-} \rightarrow \mathrm{N}_{2} \mathrm{O}}}{4} \mathrm{~N}_{2} \mathrm{O}+\frac{1}{8} \mathrm{HCO}_{3}^{-}}{4}+\left(\frac{5}{26} f_{e, \mathrm{NO}_{2}^{-} \rightarrow \mathrm{N}_{2} \mathrm{O}}-\frac{7}{104}\right) \mathrm{CO}_{2}+\left(\frac{9}{104}-\frac{6}{13} f_{e, \mathrm{NO}_{2}^{-} \rightarrow \mathrm{N}_{2} \mathrm{O}}\right) \mathrm{H}^{+}+\left(\frac{1}{104}+\frac{19}{52} f_{e, \mathrm{NO}_{2}^{-} \rightarrow \mathrm{N}_{2} \mathrm{O}}\right) \mathrm{H}_{2} \mathrm{O}
\end{aligned}
$$

A saturation-type model for heterotrophic growth systems was used to describe the rate-limiting roles of biomass, organic carbon, and electron acceptor concentrations during nitrate bioreduction (Rittmann and McCarty, 2001). The model considers nitrate reduction to nitrite and nitrite reduction to dinitrogen in coupling with organic carbon oxidation and biomass growth. The overall rates for nitrate and nitrite reduction were described using a multiplicative Monod model (Rittmann and McCarty, 2001):

$$
\begin{aligned}
r_{N O_{3}^{-}} & =\hat{q}_{N O_{3}^{-}} X \frac{C_{o c}}{K_{s, o c}^{N O_{3}^{-}}+C_{o c}} \frac{C_{\mathrm{NO}_{3}^{-}}}{K_{s, \mathrm{NO}_{3}^{-}}+C_{\mathrm{NO}_{3}^{-}}} \\
r_{\mathrm{NO}_{2}^{-}} & =\frac{\hat{q}_{\mathrm{NO}_{2}^{-}}}{1+C_{\mathrm{NO}_{3}^{-}} / K_{I}} X \frac{C_{o c}}{K_{s, o c}^{\mathrm{NO}_{2}^{-}}+C_{o c}} \frac{C_{\mathrm{NO}_{2}^{-}}}{K_{s, \mathrm{NO}_{2}^{-}}+C_{\mathrm{NO}_{2}^{-}}}
\end{aligned}
$$




$$
\begin{aligned}
& \frac{d C_{i}}{d t}=\sum_{j=N O_{3}^{-}, N O_{2}^{-}} \alpha_{i}^{j} r_{j} \\
& \frac{d X}{d t}=\sum_{j=N O_{3}^{-}, N O_{2}^{-}} \beta_{j} r_{j}-b X
\end{aligned}
$$

where $\hat{q}_{j}(\mathrm{mmol} / \mathrm{g} / \mathrm{d})$ is the maximum specific rate of utilization for electron acceptor $j\left(j=\mathrm{NO}_{3}{ }^{-}\right.$or $\left.\mathrm{NO}_{2}{ }^{-}\right) ; X(\mathrm{~g} / \mathrm{L})$ is the biomass concentration; $C_{i}(\mathrm{mM})$ is the concentration of substrates (organic carbon, $\mathrm{NO}_{3}{ }^{-}$and $\mathrm{NO}_{2}{ }^{-}$); $K_{S, o c}^{j}(\mathrm{mM})$ is the half-maximum rate constant with respect to organic carbon when electron acceptor $j$ was used; $K_{s, j}(\mathrm{mM})$ is the half-maximum rate constant with respect to electron acceptor $j ; K_{I}(\mathrm{mM})$ is the inhibition constant; ${ }^{j}{ }_{i}$ and $\beta_{j}$, which are functions of $f_{e}$, are the stoichiometric coefficients of substrate $i$ or biomass $X$ in the overall nitrate or nitrite reduction reactions, respectively; $b(1 / \mathrm{d})$ is the endogenous decay coefficient.

In the modeling, literature values for parameters $\hat{q}_{\mathrm{NO}_{3}^{-}}, \hat{q}_{\mathrm{NO}_{2}^{-}}, K_{s, o c}^{\mathrm{NO}_{3}^{-}}, K_{s, o c}^{\mathrm{NO}_{2}^{-}}, K_{s, \mathrm{NO}_{3}^{-}}, K_{s, \mathrm{NO}_{2}^{-}}$, and $b$ were first tried (Almeida et al., 1997; Ni et al., 2011, 2013; Pan et al., 2012, 2013; Wang et al., 2003), and if necessary fine-tuned to match experimental results. Parameters $f_{e, \mathrm{NO}_{3}^{-} \rightarrow \mathrm{NO}_{2}^{-}}, f_{e, \mathrm{NO}_{2}^{-} \rightarrow \mathrm{N}_{2}}$ (or $f_{e, \mathrm{NO}_{2}^{-} \rightarrow \mathrm{N}_{2} \mathrm{O}}$ for the RS), and $K_{I}$ were fitted to evaluate whether it is necessary to consider biomass growth and competitive inhibition during the nitrate and nitrite reduction in the LPZ sediments. These parameters were estimated by simultaneously matching the measured nitrate and nitrite concentrations in the reactors with variable sediment/SGW ratios and initial nitrate concentrations. The goodness of the model fit was quantified by minimizing the sum of squares of the differences between the simulated and measured values, i.e. $S=\sum_{i=1}^{n}\left(C_{i}-\hat{C}_{i}\right)^{2}$ (Bard, 1974).

For the convenience to estimate relative standard deviation of the estimated parameters $\left(\sigma\left(\theta_{k}\right) / \theta_{k}\right)$, equation 6 was rewritten with respect to fitting parameters:

$$
\frac{d C_{i}}{d t}=f\left(\boldsymbol{\theta}, C_{i}, t\right)
$$

where $C_{i}$ is the concentration of $\mathrm{NO}_{3}{ }^{-}$or $\mathrm{NO}_{2}{ }^{-}$and $\boldsymbol{\theta}$ is a vector containing fitting parameters. The variances for the estimated parameters can be calculated from a covariance matrix of the parameter estimates (Bard, 1974; Beck and Arnold, 1977; Liu and Zachara, 2001):

$$
\operatorname{Cov}(\boldsymbol{\theta})=\left(\boldsymbol{J}^{T} \boldsymbol{V}^{-1} \boldsymbol{J}\right)^{-1}
$$


where $\operatorname{Cov}(\theta)$ is a covariance matrix of the estimated parameters. $V^{-1}$ is the inverse of the covariance matrix of the measurement errors. Assuming that measurements are independent, then $V$ is a diagonal matrix with its diagonal element assumed to be proportional to the sum of squares of the errors between the measurements and simulations $(\mathbf{V}=\mathbf{S} \boldsymbol{I})$. Superscript $T$ in Eq 9 denotes the matrix transpose of sensitivity coefficient matrix $\boldsymbol{J}$ :

$$
\boldsymbol{J}=\left[\begin{array}{ccc}
\frac{\partial S_{1}}{\partial \theta_{1}} & \cdots & \frac{\partial S_{1}}{\partial \theta_{L}} \\
\vdots & \ddots & \vdots \\
\frac{\partial S_{n}}{\partial \theta_{1}} & \cdots & \frac{\partial S_{n}}{\partial \theta_{L}}
\end{array}\right]
$$

In the covariance matrix $\operatorname{Cov}(\theta)$, the value of the diagonal element is the square of standard deviation of $\theta_{k}$, i.e. $\sigma^{2}\left(\theta_{k}\right)$ (Bard, 1974; Beck and Arnold, 1977). The relative standard deviation of the estimated parameters $\left(\sigma\left(\theta_{k}\right) / \theta_{k}\right)$ will be used to discuss the uncertainty of a parameter estimate. The confidence region volume (CRV) for a set of the estimated parameters is proportional to $|\operatorname{Cov}(\boldsymbol{\theta})|^{1 / 2}$.

\section{Results and discussion}

\subsection{Nitrate bioreduction in untreated $O S$ and $R S$}

Nitrate was reduced in both untreated OS and RS sediments with relatively faster rates in the OS (Fig. 1a and 1d). No nitrate was reduced in the controls using the autoclaved sediments (Fig. S1 in SI), indicating that nitrate reduction was microbially mediated. Nitrite was an intermediate product of nitrate bioreduction as its concentration first increased with decreasing nitrate concentration, and then decreased (Fig. 1b and 1e) when nitrate was depleted or nitrate reduction rate slowed with time (Fig. 1a and 1d). Nitrite reduction was also microbially mediated because no nitrite reduction occurred in the controls (Fig. S2). Unlike nitrate bioreduction, the nitrite bioreduction rate was similar in both sediments (Fig. S2). Consequently, during the nitrate bioreduction, the accumulated nitrite concentration was higher in the OS than that in the RS (Fig. 1b and 1e). The ATP concentrations had similar trends as those for nitrite concentrations (Fig. 1c and 1f) with their peak concentrations shifted to a later time. The results indicated that initial metabolic energy production was faster than consumption, leading to the accumulation of ATP. When the rates of nitrate and nitrite bioreduction slowed down, energy consumption became faster than its production. 
OS
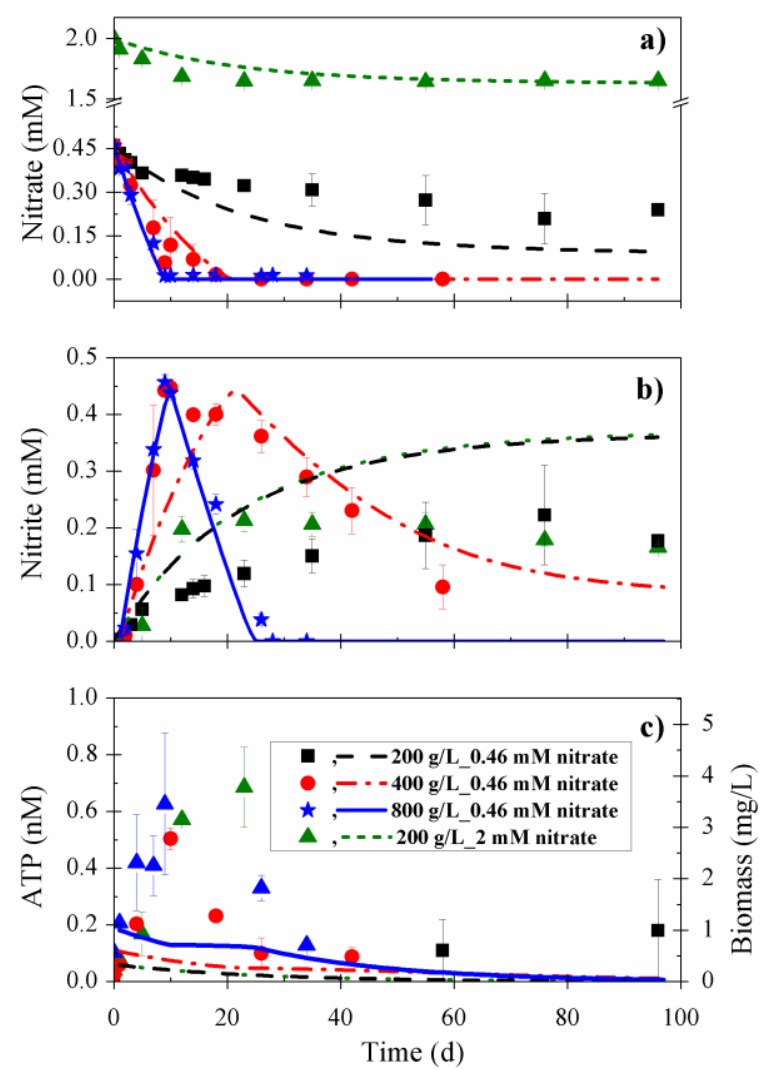

RS
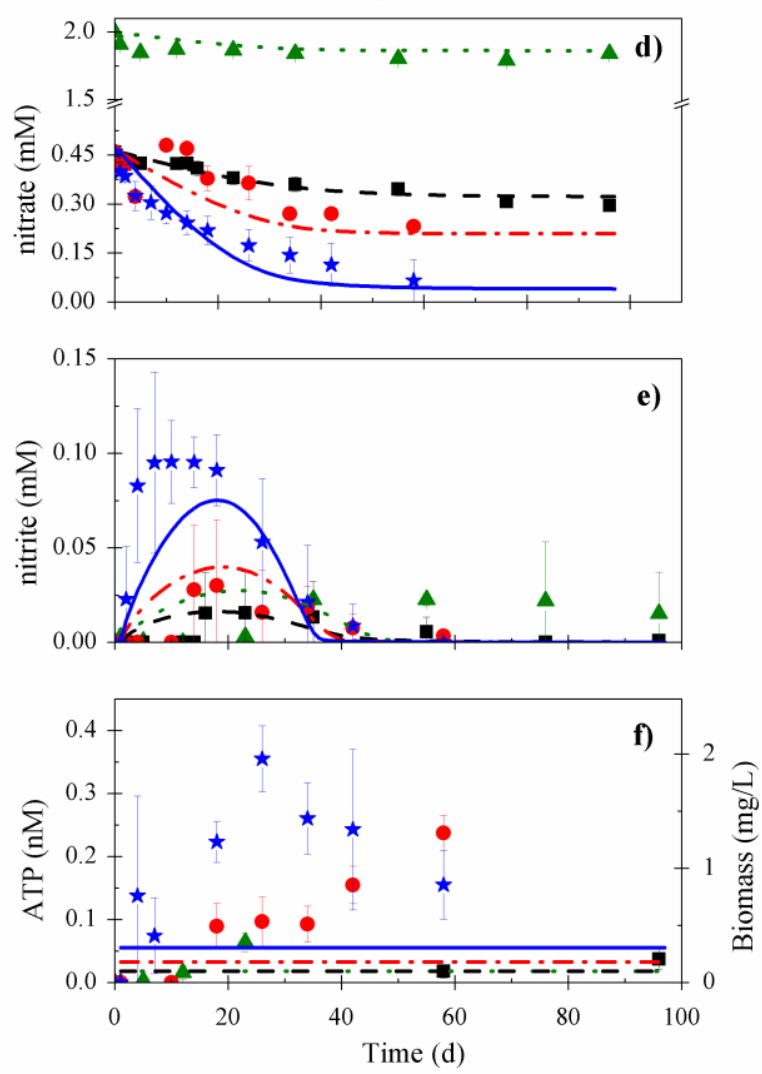

Fig. 1. Experimental and modeling results of nitrate bioreduction in the OS (plots a-c) and RS (plots d-f) suspensions under variable sediment/SGW ratios $(200,400,800 \mathrm{~g} / \mathrm{L})$ and initial nitrate concentrations $(0.46$ and 2.0 $\mathrm{mM}$ ). The figure shows nitrate reduction (plots a and d), nitrite production and reduction (plots $b$ and e), and measured ATP and simulated biomass (plots c and f). Symbols are experimental results and lines are the simulated results. The error bars denote the standard deviations of duplicate experiments.

The faster rate of nitrate bioreduction in the OS relative to the RS was unexpected in light of the general understanding that lower redox conditions favor nitrate bioreduction (Small et al., 2014). Redox condition can affect the nitrate bioreduction rate by influencing denitrifier population and gene expression, and electron donor concentration and speciation. Higher redox potential would decrease the rate of gene expression for denitrifying reductase production (Zhang et al., 2014), and would also cause the oxidation of electron donors including reduced iron and sulfur species and organic carbon, thus decreasing their capacity and bioavailability for nitrate bioreduction and lead to a lower rate of nitrate bioreduction (Van Trump et al., 2011). The faster nitrate bioreduction rate in the OS, despite that the RS contained over 9 times of organic carbon than the OS, was, however, qualitatively consistent with the variation in denitrifier population in the sediments (Table 1). A likely reason for the lower population of 
denitrifiers in the RS is the long-term adaption of denitrifiers at the site where the low permeability of the LPZ and faster nitrate bioreduction in the OS made nitrate less available for the RS, which locates below the OS. Consequently, the microbial community in the RS is adapted to low or no nitrate condition.

The rates of nitrate bioreduction generally increased with increasing sediment/SGW ratio in both OS and RS (Fig. 1), indicating that a higher sediment-associated initial organic carbon content and biomass led to a higher nitrate bioreduction rate. In the OS, nitrate and its reduction product nitrite were reduced completely at sediment/SGW ratio of $800 \mathrm{~g} / \mathrm{L}$, but only partially at $200 \mathrm{~g} / \mathrm{L}$ (Fig. 1a and 1b). In the RS, nitrate was only bioreduced partially at all sediment/SGW ratios (Fig. 1d and 1e). The partial nitrate bioreduction that depended on the initial sediment/SGW ratio could be attributed to the limitation of organic carbon in the sediment. When organic carbon was higher in the higher solid/SGW ratio reactor, more nitrate was reduced. Based on the stoichiometric balance as described by reactions 1-3 and the extents of nitrate and nitrite reduction (Fig. 1), only $4.3 \%$ and $0.22 \%$ of the indigenous organic carbon was involved or bioavailable for nitrate bioreduction in the OS and RS, respectively. The much lower bioavailable organic carbon than the total organic carbon in both sediments suggested that most of the labile organic carbon had been consumed in field.

\subsection{Effects of organic carbon and initial nitrate concentration on nitrate bioreduction}

Spiking organic substrates significantly increased the rates of nitrate and nitrite bioreduction in the OS (Fig. 2), confirming that organic carbon was a key rate-limiting factor. Without added exogenous organic carbon, nitrate and nitrite concentrations stabilized after 10-20 days of incubation depending on initial nitrate concentrations, and only $25 \%$ of nitrate was reduced at the end of experiment (Fig. 2a). With the spiked organic substrates, nitrate was completely reduced within 3 days, and nitrite was produced and then completely reduced within 7 days (Fig. 2b). The total concentration of spiked organic carbon was $0.324 \mathrm{mg} \mathrm{C} / \mathrm{g}$ of sediment after normalizing to the sediment mass. This value represented 65\% of total indigenous organic carbon in the OS (Table 1), indicating that organic carbon bioavailability was an important factor influencing nitrate bioreduction. Moreover, it is interesting to observe that nitrite in un-spiked OS reactors (Fig. 2a) accumulated to a common asymptotic value $(\sim 0.2 \mathrm{mM})$ as a result of $\sim 0.2 \mathrm{mM}$ of nitrate reduction, despite with different initial nitrate concentrations. The common asymptotic accumulation of nitrite is likely due to the incomplete nitrate bioreduction limited by the low organic carbon content and bioavailability in the OS. 

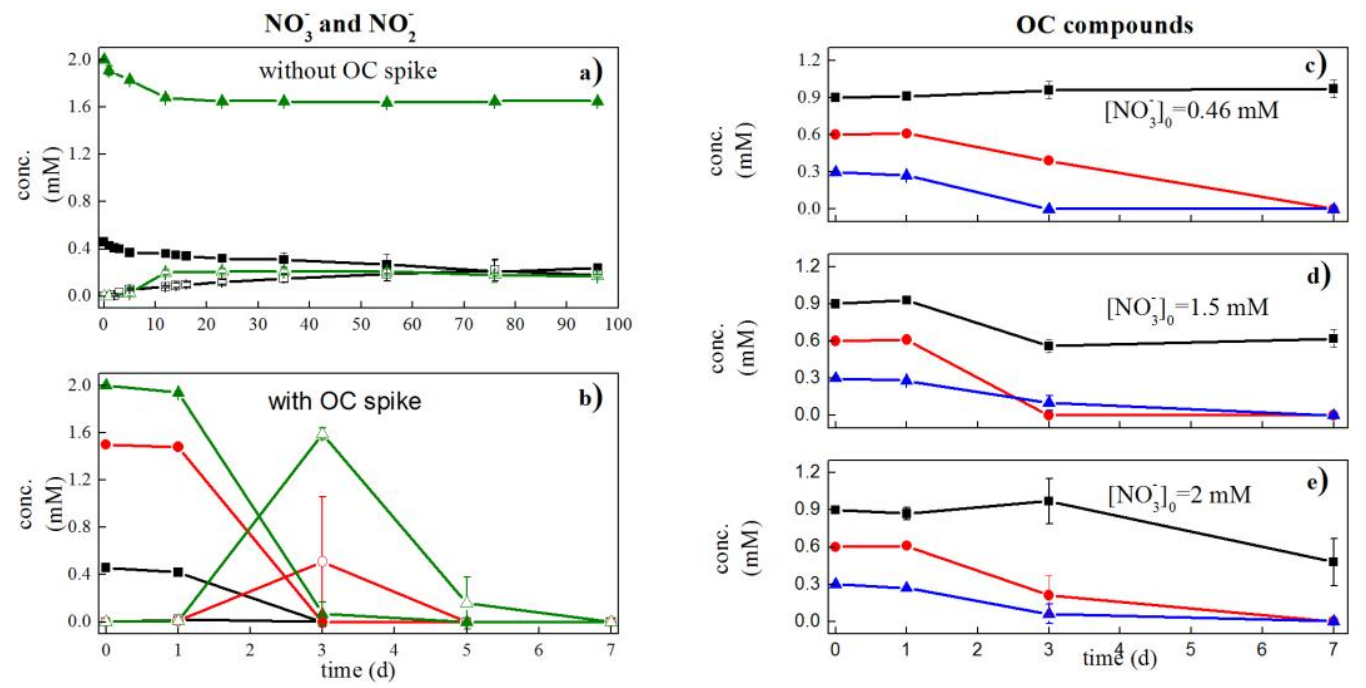

Fig. 2. Nitrate reduction, and nitrite production and reduction in the OS suspensions with different initial nitrate concentrations, and with/without spiked organic carbon $(\mathrm{OC})$. Sediment $/ \mathrm{SGW}$ ratio $=200 \mathrm{~g} / \mathrm{L}$. Plot a: nitrate and nitrite concentrations without $\mathrm{OC}$ spike (symbol $\square$ for $\mathrm{NO}_{3}{ }^{-}$and symbol $\square$ for $\mathrm{NO}_{2}{ }^{-}$under initial $\mathrm{NO}_{3}{ }^{-}=0.46$ $\mathrm{mM}$; symbol $\boldsymbol{\Delta}$ for $\mathrm{NO}_{3}{ }^{-}$and symbol $\triangle$ for $\mathrm{NO}_{2}{ }^{-}$under initial $\mathrm{NO}_{3}{ }^{-}=2 \mathrm{mM}$ ), Plot b: nitrate and nitrite concentrations with OC spike (symbol $\square$ for $\mathrm{NO}_{3}^{-}$and symbol $\square$ for $\mathrm{NO}_{2}^{-}$under initial $\mathrm{NO}_{3}^{-}=0.46 \mathrm{mM}$; symbol $\bigcirc$ for $\mathrm{NO}_{3}{ }^{-}$and symbol $\bigcirc$ for $\mathrm{NO}_{2}{ }^{-}$under initial $\mathrm{NO}_{3}{ }^{-}=1.5 \mathrm{mM}$; symbol $\boldsymbol{\Delta}$ for $\mathrm{NO}_{3}{ }^{-}$and symbol $\triangle$ for $\mathrm{NO}_{2}{ }^{-}$under initial $\mathrm{NO}_{3}{ }^{-}=2 \mathrm{mM}$ ), plot $\mathbf{c}, \mathbf{d}$ and $\mathbf{e}$ : spiked $\mathrm{OC}$ compound concentrations corresponding to nitrate reduction in plot $\mathbf{b}$ under different initial $\mathrm{NO}_{3}{ }^{-}$concentrations (symbol $\mathbf{\square}$ for acetate, symbol $\bullet$ for lactate, and symbol $\boldsymbol{\Delta}$ for glucose). The error bars denote the standard deviations of duplicate experiments.

The rate-limiting effect of organic carbon was consistent with other reports in the literature (Pulou et al., 2012; Weymann et al., 2010). In some river and stream sediments, however, nitrate bioreduction via denitrification was not limited by organic carbon content (Herrman et al., 2008; Jha and Minagawa, 2013; Laverman et al., 2010). Analysis of these different cases indicated that $10 \mathrm{mg} \mathrm{C} / \mathrm{g}$ of sediment was the boundary dividing whether organic carbon would limit denitrification (Herrman et al., 2008). When organic carbon content is lower than $10 \mathrm{mg} \mathrm{C} / \mathrm{g}$ of sediment, denitrification would be limited by organic carbon. The total organic carbon contents were 0.6 and $5.3 \mathrm{mg}$ $\mathrm{C} / \mathrm{g}$ of sediment in the OS and RS, respectively, consistent with this classification of the rate-limiting role of organic carbon. Furthermore, our results highlighted that organic carbon bioavailability played even more important role than the total organic carbon in limiting nitrate bioreduction. 
Among spiked organic substrates, glucose and lactate were preferentially used, and then acetate (Fig. 2c-2e). The sequence of organic carbon degradation and assimilation by microorganisms is an important, but unresolved question in understanding and predicting microbial activities in soils and sediments (Bahr et al., 2011). Free energy, molecular structure, and redox state of organic compounds have been proposed as major factors governing the sequence of their utilization (Bahr et al., 2011). Glucose, lactate and acetate have different free energies and molecular structure, and are the most commonly employed OC sources for denitrification. The results in Fig. 2c indicated the incongruent consumption of these OC sources, and were approximately consistent with the free energies involved in the respiration reaction of OC oxidation and nitrate reduction as glucose $(-2686 \mathrm{~kJ} / \mathrm{reaction})$ yielded more energy than lactate $(-1260 \mathrm{~kJ} /$ reaction), and lactate more than acetate $(-843 \mathrm{~kJ} /$ reaction) (Cervantes, 2009). However, when normalizing the reaction free energy to each carbon in the organic compounds, the difference in reaction free energy using these different organic carbon species was small (420 to $447 \mathrm{~kJ} / \mathrm{reaction}$ ). The sequence of organic compound degradation in Fig. 2c was also in contrast to the molecular structure explanation as acetate has a simpler molecular structure than lactate and glucose. It was not consistent with the redox potential trend either because the average redox state of carbon is the same (valence $=0$ ) in these three organic compounds. Further research is needed to understand factors controlling the degradation and assimilation of organic substrates.

Spiking organic carbon also enhanced nitrate bioreduction in the RS, but to a much less degree than the OS (Fig. 3). The rates of nitrate bioreduction in the RS with organic carbon addition (Fig. 3b) were 10-20\% higher than those without spiked organic carbon (Fig. 3a). This result was in contrast to the OS where the rate of nitrate bioreduction increased 50 times after organic carbon addition (Fig. 2). The result, together with that increasing sediment/SGW ratio significantly increased the rate of nitrate bioreduction (Fig. 1d and 1e), indicated that nitrate bioreduction was more limited by denitrifier population and gene expression in the RS (Table 1). The sequence of organic carbon degradation in the RS was, however, the same as that in the OS (Fig. 3c). Sulfate concentration change was negligible (Fig. S3) during nitrate bioreduction. This observation is consistent with the result of longterm (3-year) nitrate bioreduction reported by Percak-Dennet and Roden (2014), which demonstrated that nitrate bioreduction in the LPZ sediment was driven by heterotrophic denitrification. The enhanced aqueous sulfate concentration in the OS on day 1 (Fig. S3) resulted from the release of sediment-associated sulfate, which was confirmed by the quick leaching of sulfate into DI-water from the OS. In addition, ammonium production was not 
observed (data not shown), suggesting that dissimilatory reduction of nitrate to ammonium was negligible in both sediments.
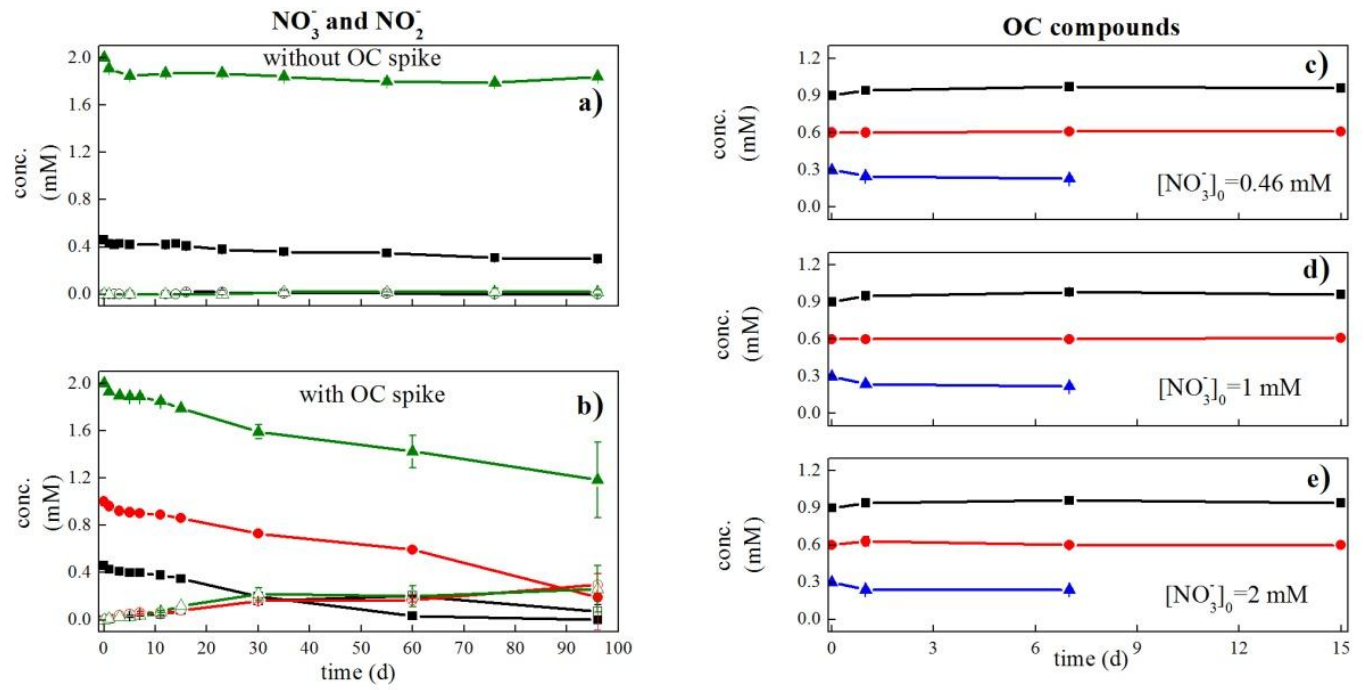

Fig. 3. Nitrate reduction, and nitrite production and reduction in the RS suspensions with different initial nitrate concentrations, and with/without spiked organic carbon $(\mathrm{OC})$. Sediment $/ \mathrm{SGW}$ ratio $=200 \mathrm{~g} / \mathrm{L}$. Plot a: nitrate and nitrite concentrations without $\mathrm{OC}$ spike (symbol $\boldsymbol{\square}$ for $\mathrm{NO}_{3}{ }^{-}$and symbol $\square$ for $\mathrm{NO}_{2}{ }^{-}$under initial $\mathrm{NO}_{3}{ }^{-}=0.46$ $\mathrm{mM}$; symbol $\boldsymbol{\Delta}$ for $\mathrm{NO}_{3}{ }^{-}$and symbol $\triangle$ for $\mathrm{NO}_{2}{ }^{-}$under initial $\mathrm{NO}_{3}{ }^{-}=2 \mathrm{mM}$ ), Plot b: nitrate and nitrite concentrations with OC spike (symbol $\square$ for $\mathrm{NO}_{3}^{-}$and symbol $\square$ for $\mathrm{NO}_{2}{ }^{-}$under initial $\mathrm{NO}_{3}{ }^{-}=0.46 \mathrm{mM}$; symbol $\bullet$ for $\mathrm{NO}_{3}{ }^{-}$and symbol $\bigcirc$ for $\mathrm{NO}_{2}{ }^{-}$under initial $\mathrm{NO}_{3}{ }^{-}=1.5 \mathrm{mM}$; symbol $\boldsymbol{\Delta}$ for $\mathrm{NO}_{3}{ }^{-}$and symbol $\triangle$ for $\mathrm{NO}_{2}{ }^{-}$under initial $\mathrm{NO}_{3}{ }^{-}=2 \mathrm{mM}$ ), plot $\mathbf{c}, \mathbf{d}$ and $\mathbf{e}$ : spiked $\mathrm{OC}$ compound concentrations corresponding to nitrate reduction in plot $\mathbf{b}$ under different initial $\mathrm{NO}_{3}{ }^{-}$concentrations (symbol $\mathbf{\square}$ for acetate, symbol $\boldsymbol{\bullet}$ for lactate, and symbol $\boldsymbol{\Delta}$ for glucose). The error bars denote the standard deviations of duplicate experiments.

Increasing initial nitrate concentration had a minor effect on the nitrate bioreduction in both sediments without organic carbon addition (Fig. 2a and 3a). In order to compare the nitrate bioreduction rate between the OS and RS, a pseudo first-order rate with respect to nitrate concentration was estimated as described below. When initial nitrate concentration increased from 0.46 to $2 \mathrm{mM}$, the observed pseudo first-order nitrate bioreduction rates only increased from 0.005 to $0.006 \mathrm{mM} / \mathrm{d}$ in the OS and from 0.002 to $0.003 \mathrm{mM} / \mathrm{d}$ in the RS. The result was expected given that nitrate bioreduction in the OS was mainly limited by organic carbon, while the bioreduction in the RS was mainly controlled by denitrifier population and gene expression as mentioned above. When organic carbon limitation was 
removed by spiking organic substrates, nitrate bioreduction rate increased with increasing nitrate concentration in the OS (Fig. 2b). In the RS reactors spiked with organic substrates, however, the rate of nitrate bioreduction only increased from 0.005 to $0.007 \mathrm{mM} / \mathrm{d}$ when nitrate concentration increased from 0.46 to $2 \mathrm{mM}$, indicating that the initial nitrate concentration had negligible impact on the nitrate bioreduction in the RS. This was consistent with the observation that the nitrate bioreduction rate in the RS was mainly limited by denitrifier population.

\subsection{End product of nitrate bioreduction}

$\mathrm{N}_{2} \mathrm{O}$ was an intermediate product of nitrate bioreduction in the OS as its concentration initially increased and then decreased (Fig. 4a). $\mathrm{N}_{2} \mathrm{O}$ concentration increased as nitrate and nitrite were reduced (Fig. 2). When nitrate was depleted, $\mathrm{N}_{2} \mathrm{O}$ concentration decreased with time. As an intermediate species, $\mathrm{N}_{2} \mathrm{O}$ concentration was affected by the rate of $\mathrm{N}_{2} \mathrm{O}$ production from nitrate and nitrite reduction, and $\mathrm{N}_{2} \mathrm{O}$ reduction to $\mathrm{N}_{2}$. The results indicated that the $\mathrm{N}_{2} \mathrm{O}$ bioreduction in the OS was a fast process as its concentration was low and quickly decreased to zero once nitrate and nitrite were completely reduced (Fig. 2 and 4). A slight shift of $\mathrm{N}_{2} \mathrm{O}$ concentration profile to the late time in the case of $2 \mathrm{mM} \mathrm{NO}_{3}^{-}$was apparently caused by the higher initial concentration of nitrate, and the subsequent accumulation of nitrite required a longer time to completely transform to $\mathrm{N}_{2} \mathrm{O}$ (Fig. 2b). In the $\mathrm{RS}, \mathrm{N}_{2} \mathrm{O}$ accumulated to a much higher concentration than in the OS (Fig. 4b). Nitrogen mass balance calculation (Table S3) by considering the equilibrium of $\mathrm{N}_{2} \mathrm{O}$ in gas and aqueous phases indicated that almost all reduced nitrate (91-102\%) was transformed to $\mathrm{N}_{2} \mathrm{O}$. The continuous, quantitative accumulation of $\mathrm{N}_{2} \mathrm{O}$ as a result of nitrate and nitrite reduction indicated that $\mathrm{N}_{2} \mathrm{O}$ was the end product of nitrate bioreduction in the RS. 


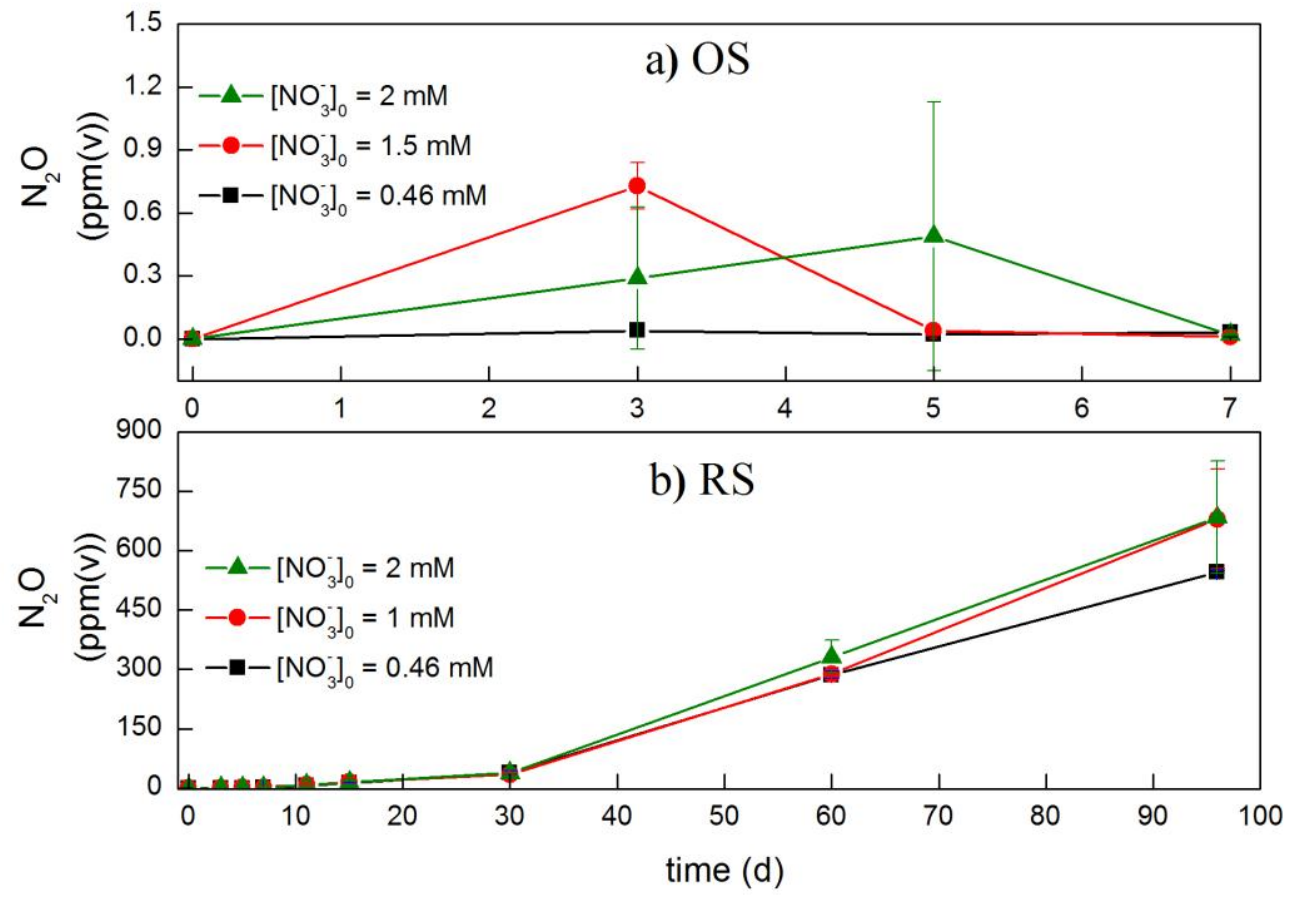

Fig. 4. Temporal evolution of $\mathrm{N}_{2} \mathrm{O}$ concentration in the reactor headspaces during the nitrate bioreduction in the OS (a) and RS (b) suspensions under variable initial nitrate concentrations corresponding to those in plot b in Figures 2 and 3. Sediment $/ \mathrm{SGW}$ ratio $=200 \mathrm{~g} / \mathrm{L}$ with $\mathrm{OC}$ spike. The error bars denote the standard deviations of duplicate experiments.

The reduction of $\mathrm{N}_{2} \mathrm{O}$ to $\mathrm{N}_{2}$ in the OS was consistent with the quantitative PCR measurements that showed the abundance of nosZ gene in the OS upon incubation (Table 1). Lin et al. (2012a) found that the denitrifier population in Hanford subsurface sediment was dominated by Ochrobactrum anthropi, and its nosZ clones had 97\% similarity with Ochrobactrum anthropiYD50.2, which can tolerate up to $100 \mathrm{mM}$ nitrite. The increase and then decrease with time in $\mathrm{N}_{2} \mathrm{O}$ concentration (Fig. 4a) indicated that nos $\mathrm{Z}$ was expressed and $\mathrm{N}_{2} \mathrm{O}$ reductase functional in the OS upon incubation. In the RS, however, the quantitative production of $\mathrm{N}_{2} \mathrm{O}$ from nitrate and nitrite reduction indicated that $\mathrm{N}_{2} \mathrm{O}$ reductase did not exist or its activity was inhibited. Undetectable nos $Z$ gene in the RS (Table 1) reflected little or no potential for $\mathrm{N}_{2} \mathrm{O}$ reduction, and led to the $\mathrm{N}_{2} \mathrm{O}$ accumulation as the end product of nitrate bioreduction. The long-term adaptation of the denitrifiers at the site as speculated before for the low denitrifier population in the RS might also be responsible for the low or non-existence of nos $Z$ gene. 


\subsection{Kinetic model analysis}

Various models have been proposed to describe nitrate bioreduction including multiplicative Monod model (Henze et al., 2000; Rittmann and McCarty, 2001), enzyme-based model (Hamilton et al., 2005), and modified Monod model with electron competition (Ni et al., 2011; Ni et al., 2013; Pan et al., 2013). All models adopt saturation-type expression with respect to electron donor and acceptor concentrations, but with different ways to balance mass and electron for the reactions involved in nitrate bioreduction. The rate-limiting role of organic carbon and microbial biomass in the sediments as described before indicated that a multiplicative saturation-type model is needed to describe the nitrate and nitrite bioreduction in the LPZ sediments. The multiplicative Monod model was modified by adding an inhibition term to account for the electron competition between nitrate and nitrite bioreduction (first part containing $K_{I}$ in the right hand side of Eq 5). This inhibition term is required to describe the phenomenon in Fig. 1a and 1b, which showed that nitrite reduction started only after nitrate reduction was completed in the OS. The electron competition concept (Ni et al., 2011; Ni et al., 2013; Pan et al., 2013) assumed that the electrons generated from organic carbon oxidation can be competitively used by different reductases involved in the nitrate bioreduction (Richardson et al., 2009). The kinetic model as described by Eqs 4-7 with parameters provided in Table 2 was able to simultaneously describe nitrate and nitrite concentration changes as a function of time under variable solid/SGW ratios (i.e. initial biomass and organic carbon concentrations) and initial nitrate concentrations (Fig. 1).

Although most nitrate and nitrite concentration profiles were fitted well by the model (Eqs 4-7), discrepancy still existed between the model and measured results. In the OS, the simulated nitrate and nitrite concentrations for the $0.46 \mathrm{mM}$ nitrate treatment at 400 and $800 \mathrm{~g} / \mathrm{L}$ solid water ratio matched well with the measured values, while the simulated nitrate and nitrite concentrations for the $0.46 \mathrm{mM}$ nitrate treatment at $200 \mathrm{~g} / \mathrm{L}$ were lower and higher than the corresponding measured values, respectively. For the treatment with $2 \mathrm{mM}$ nitrate at $200 \mathrm{~g} / \mathrm{L}$, nitrate was fitted well but the simulated nitrite concentrations were higher than the experimental results. In the RS, the nitrate concentrations were simulated well for most batch experiments except for the treatment with $0.46 \mathrm{mM}$ nitrate at 400 $\mathrm{g} / \mathrm{L}$ solid water ratio, for which the simulated nitrite concentrations were either lower or close to the measured values. It's important to note that the model was used to simultaneously fit all the treatments using a common set of model parameters. Fitting can be improved by adjusting parameters for each treatment (results not shown), 
suggesting that the model parameters changed with experimental conditions. These changes, however, are within the uncertainty ranges as discussed below (Table 2). The ATP results were poorly described by the model. In the simulation, ATP was treated as a surrogate for the biomass of denitrifiers. Comparing the modeling and experimental results indicated that the ATP concentration changed more dynamically than the simulated biomass. Similar phenomena were observed previously in the growth of fermentative bacteria in cultures and microbial growth in moist soils (Meyer and Papoutsakis, 1989; Nannipieri et al., 1978), suggesting that ATP was not a good indicator for modeling the dynamic change of biomass in the LPZ sediments. The poor correlation of ATP content with total biomass concentrations would be expected, because the ATP content of the sample should somewhat reflect the product of the biomass concentration and the cell-specific activity. Moreover, the simulated biomass was independent of initial nitrate concentration (Fig. 1). This can be seen in the two treatments with different initial nitrate concentrations at the same solid/water ratio (Fig. 1c). The result is consistent with the experimental observation that the bioavailability of sediment-associated organic carbon limited the rate of nitrate bioreduction in the sediments, and consequently the change in nitrate concentration had negligible effect on biomass growth. Difference in simulated biomass at different solid/water ratio is because of the difference in initial biomass in the reactors.

Table 2 Parameters used for simulation in the OS and RS.

\begin{tabular}{|c|c|c|c|c|c|}
\hline \multirow{2}{*}{ Kinetic Parameters } & \multicolumn{2}{|c|}{ OS } & \multicolumn{2}{|c|}{ RS } & \multirow{2}{*}{$\begin{array}{l}\text { Literature } \\
\text { Values }\end{array}$} \\
\hline & $\theta$ & $\sigma(\theta) / \theta$ & $\theta$ & $\sigma(\theta) / \theta$ & \\
\hline $\mathrm{XO}(\mathrm{g} / \mathrm{L})$ & $2.1 \times 10^{-6}$ & 1.4 & $7.2 \times 10^{-7}$ & 11.8 & - \\
\hline Bioavailable OC (\%) & 4.3 & 8.0 & 0.18 & 1.0 & - \\
\hline$\hat{q}_{N O_{3}^{-}}(\mathrm{mmol} \cdot \mathrm{g}-1 \cdot \mathrm{d}-1)$ & 140 & 1.5 & 185 & 12.7 & $55^{a}-203^{b}$ \\
\hline$\hat{q}_{N O_{2}^{-}}(\mathrm{mmol} \cdot \mathrm{g}-1 \cdot \mathrm{d}-1)$ & 170 & 5.9 & 85 & 12.0 & $28^{a}-96^{b}$ \\
\hline$K_{s, o c}^{\mathrm{NO}_{3}^{-}}(\mathrm{mM})$ & 0.1 & - & 0.1 & - & $0.1^{\mathrm{b}}$ \\
\hline$K_{s, o c}^{\mathrm{NO}_{2}^{-}}(\mathrm{mM})$ & 0.1 & - & 0.001 & 364 & $0.1^{\mathrm{b}}$ \\
\hline$K_{s, \mathrm{NO}_{3}^{-}}(\mathrm{mM})$ & 0.0018 & - & 0.1 & 14.2 & $0.002^{b}-0.003^{a}$ \\
\hline$K_{s, \mathrm{NO}_{2}^{-}}(\mathrm{mM})$ & 0.0041 & - & 0.0041 & - & $0.0041^{b}$ \\
\hline$K_{I(\mathrm{mM})}$ & 0.0039 & 39.5 & 20 & 63.0 & - \\
\hline$f_{e, \mathrm{NO}_{3}^{-} \rightarrow \mathrm{NO}_{2}^{-}}$ & 0.999 & 0.5 & 1 & - & $0.5^{c}$ \\
\hline
\end{tabular}




\begin{tabular}{cccccc}
\hline$f_{e, \mathrm{NO}_{2}^{-} \rightarrow N_{2}}$ & 0.94 & 2.1 & - & - & - \\
$f_{e, \mathrm{NO}_{2}^{-} \rightarrow \mathrm{N}_{2} \mathrm{O}}$ & - & - & 1 & - & - \\
$\mathrm{b}(\mathrm{d}-1)$ & 0.04 & 5.0 & 0 & - & $<0.05^{c}$ \\
$\mathrm{CRV}$ & - & 233 & - & $4.8 \times 10^{5}$ & - \\
\hline
\end{tabular}

${ }^{\mathrm{a}}$ Parameters from Almeida et al., 1997; ${ }^{\mathrm{b}}$ parameters from Pan et al., 2013; ${ }^{\mathrm{c}}$ parameters from Pan et al., 2013 and Rittmann and McCarty, 2001

The estimated inhibition concentration of nitrate $\left(K_{I}\right)$ for nitrite reduction was $0.0039 \mathrm{mM}$ in the OS (Table 2), which was much smaller than the initial nitrate concentration $(0.46-2 \mathrm{mM})$ used in the experiments. While this is an empirically fitted parameter to match the experimental data, the small $K_{I}$ value suggested that the reactivity of nitrite reductases in the OS was strongly inhibited by the presence of nitrate. The macroscopic effect is that nitrite reduction in the OS started after the completion of nitrate reduction. In the RS, the fitting $K_{I}$ value was $20 \mathrm{mM}$, suggesting that nitrate had little impact on nitrite reduction. The large $K_{I}$ reflected the fact that nitrite reduction in the RS was not inhibited by the presence of $0.46-2.0 \mathrm{mM}$ nitrate (Fig. 1d and 1e). These results support the assumption of electron competition between the nitrate and nitrite reductases. When the nitrate reduction rate was faster than nitrite reduction in the OS, electrons generated from organic carbon oxidation were less available for nitrite reductase. On the other hand, when nitrate reduction rate was slower than or close to nitrite reduction in the RS, nitrite reductases was able to effectively compete for electrons with nitrate reductases.

The values of most other model parameters were generally consistent with those reported in the literature (Table 2). Some differences exist, however. The much larger fitted values of $f_{e}$ than those reported in the literature for nitrate and nitrite bioreduction indicated that biomass synthesis was small in the OS $\left(f_{e}>0.9\right)$, and negligible in the $\mathrm{RS}\left(f_{e}=1\right)$. The result indicated that almost all electrons and energy generated from organic carbon oxidation were used for the respiration, suggesting that the nitrate and nitrite concentrations can be simulated by ignoring the growth term. Model simulations by ignoring the growth term (i.e., setting $f_{e}=1$ in reactions 1 to 3 ) confirmed this conclusion (results not shown). In the RS, a larger fitted $K_{s, \mathrm{NO}_{3}^{-}}$value with respect to nitrate was used to match the slow rate of nitrate reduction (Fig. 1d), and a smaller value of $K_{s, \mathrm{NO}_{3}^{-}}$with respect to organic carbon was used to match the relative faster reduction of nitrite (Fig. 1e). 
The estimated parameters contained large uncertainties (Table 2). This is expected because a previous theoretical analysis revealed that the kinetic parameters in the saturation-type models are linearly correlated and the relative standard deviation (i.e., $\sigma\left(\theta_{k}\right) / \theta_{k}$ ) of correlated parameters could be as large as 80 depending on experimental conditions (Liu and Zachara, 2001). The relative standard deviation of all the estimated parameters except for $K_{s, o c}^{\mathrm{NO}_{2}^{-}}$in this study ranged from 0.5 to 63 , within the theoretical ranges described above. The larger uncertainties for $K_{s, o c}^{\mathrm{NO}_{2}^{-}}$value in the RS, was attributed to the larger variations in the measured nitrate and nitrite concentrations as shown by the large value of CRV (Table 2). Because of the correlated nature of the kinetic parameters, their estimated values should be used in sets to minimize simulation uncertainties.

\section{Conclusions}

This study found that organic carbon bioavailability and gene expression can play critical roles in determining the rate and end product of nitrate bioreduction in the LPZ sediments, highlighting that a common assumption that organisms capable of denitrification are ubiquitous in the subsurface environment has a limitation. The lower rate of nitrate bioreduction in the reduced than that in the oxidized LPZ sediments was also in contrast to the observations in river and lake sediments where nitrate bioreduction is typically faster in more reduced sediments. Long-term adaptation of microbial community to the biogeochemical environment in the LPZ was the likely cause. The microbial community in the deeper region of the LPZ has less chance to access nitrate because nitrate would be consumed when it diffuses from the overlying aquifer. This study also indicated that the bioavailable organic carbon can be much less than the total organic carbon in the LPZ sediments. Using total organic carbon for modeling would significantly over-estimate the potential and rates of microbial activities. In addition, modeling analysis indicated that the denitrification model in the LPZ can be simplified by ignoring growth term under natural conditions. Moreover, the model for predicting nitrate migration in the LPZ systems will need to carefully consider organic carbon bioavailability and the incongruent carbon substrate utilization by the bacteria consortium, functional gene expression, and redox heterogeneity in the rate and end product of nitrate bioreduction in the LPZ sediments. The LPZ, such as an aquitard, typically separates upper and lower aquifers in subsurface systems. When groundwater

tables unequally change in the aquifers through preferential recharge or pumping extraction in one aquifer, a hydraulic pressure gradient will form, which can force groundwater flow from one aquifer to the other through the 
LPZ. The result in this study indicated that nitrate carried by groundwater can be retarded and removed through bioreduction in the LPZ. On the other hand, $\mathrm{N}_{2} \mathrm{O}$ may be produced in the aquitard and carried by the groundwater into the receiving aquifer, affecting the groundwater quality and chemical composition. Consequently the bioreduction of nitrate and reducing products in the LPZ needs to be carefully considered in groundwater quality control and management.

\section{Acknowledgments}

This research is supported by the U.S. DOE, Office of Biological and Environmental Research (BER) as part of the Subsurface Biogeochemical Research (SBR) Program through Pacific Northwest National Laboratory (PNNL) SBR Science Focus Area Research Project. Part of this research was performed in Environmental Molecular Science Laboratory, a user facility sponsored by the DOE's Office of BER and located at PNNL. PNNL is operated for DOE by Battelle Memorial Institute under contract DE-AC05-76RL01830. S. Y. would like to acknowledge the fellowship from the China Scholarship Council. We also thanks anonymous reviewers for their careful reading and constructive comments. 


\section{References}

Ahn Y.H., 2006. Sustainable nitrogen elimination biotechnologies: A review. Process Biochem. 41:17091721.

Almeida, J.S., Reis, M.A.M., Carrondot, M.J.T., 1997. A unifying kinetic model of denitrification. J. Theor Biol. 186: 241-249.

Arighi, L.; Haggerty, R.; Myrold, D. D.; Iverson, J.; Baham, J. E.; Madin, I. P.; Arendt, J., 2005, Nitrate attenuation in the Missoula Flood Deposits Aquitard (Willamette Silt) of the Willamette Valley, Oregon, AGU Fall Meeting Abstracts 12/2005.

Babbin, A.R., Keil, R.G., Devol, A.H., Ward, B.B., 2014. Organic matter stoichiometry, flux, and oxygen control nitrogen loss in the ocean. Science 344, 406-408.

Bahr, M., Stams, A.J.M., De la Rosa, F., Garcia-Encina, P.A., Munoz, R., 2011. Assessing the influence of the carbon oxidation-reduction state on organic pollutant biodegradation in algal-bacterial photobioreactors. Appl. Microbiol. Biotechnol. 90, 1527-1536.

Bard Y., 1974. Nonlinear parameter estimation. Academic Press, New York.

Beck, J.V., Arnold, K.J., 1977. Parameter estimation in engineering and science. John Wiley \& Sons Inc, New York

Bjornstad, B.N., Horner, J.A., Vermeul, V.R., Lanigan, D.C., Thorne, P.D., 2009. Borehole completion and conceptual hydrogeologic model for the IFRC well field, 300 Area, Hanford Site. Pacific Northwest National Laboratory, Richland, WA.

Butterbach-Bahl, K., Baggs, E.M., Dannenmann, M., Kiese, R., Zechmeister-Boltenstern, S., 2013. Nitrous oxide emissions from soils: How well do we understand the processes and their controls? Philos. Trans. R. Soc. B 368 .

Cervantes, F.J., 2009, Environmental Technologies to Treat Nitrogen Pollution. IWA Publishing, London.

Firestone, M.K., Firestone, R.B., Tiedje, J.M., 1980. Nitrous-oxide from soil denitrification: Factors controlling its biological production. Science 208, 749-751.

Hamilton R, Casasus A, Rasche M, Narang A, Svoronos SA, Koopman B, 2005. Structured model for denitrifier dialuxic growth. Biotechnol. Bioeng. 90:501-508. 
Henze M, Gujer W, Mino T, Van Loosedrecht M, 2000. Activated sludge models ASM1, ASM2, ASM2d and ASM3 vol 9. IWA Scientific and Technical Report, London, U.K.

Herrman, K.S., Bouchard, V., Moore, R.H., 2008. Factors affecting denitrification in agricultural headwater streams in Northeast Ohio, USA. Hydrobiologia 598, 305-314.

Jha, P.K., Minagawa, M., 2013. Assessment of denitrification process in lower Ishikari river system, Japan. Chemosphere 93, 1726-1733.

Kampschreur, M.J., Temmink, H., Kleerebezem, R., Jetten, M.S.M., van Loosdrecht, M.C.M., 2009. Nitrous oxide emission during wastewater treatment. Water Res. 43, 4093-4103.

Laverman, A.M., Van Cappellen, P., van Rotterdam-Los, D., Pallud, C., Abell, J., 2006. Potential rates and pathways of microbial nitrate reduction in coastal sediments. FEMS Microbiol. Ecol. 58, 179-192.

Laverman, A.M., Garnier, J.A., Mounier, E.M., Roose-Amsaleg, C.L., 2010. Nitrous oxide production kinetics during nitrate reduction in river sediments. Water Res. 44, 1753-1764.

Lee, J.H., Fredrickson, J.K., Kukkadapu, R.K., Boyanov, M.I., Kemner, K.M., Lin, X.J., Kennedy, D.W., Bjornstad, B.N., Konopka, A.E., Moore, D.A., Resch, C.T., Phillips, J.L., 2012. Microbial reductive transformation of phyllosilicate Fe(III) and U(VI) in fluvial subsurface sediments. Environ. Sci. Technol. 46, 3721-3730.

Lin, X.J., Kennedy, D., Peacock, A., McKinley, J., Resch, C.T., Fredrickson, J., Konopka, A., $2012 \mathrm{a}$. Distribution of microbial biomass and potential for anaerobic respiration in Hanford Site 300 Area subsurface sediment. Appl. Environ. Microbiol. 78, 759-767.

Lin, X.J., Kennedy, D., Fredrickson, J., Bjornstad, B., Konopka, A., 2012b. Vertical stratification of subsurface microbial community composition across geological formations at the Hanford Site. Environ. Microbiol. 14:414-425.

Liu C.X. and Ball W.P., 2002, Back Diffusion of chlorinated solvent contaminants from a natural aquitard to a remediated aquifer under well-controlled field conditions: predictions and measurements, Groundwater, 40, 175-184

Liu, C.X., Shang, J.Y., Kerisit, S., Zachara, J.M., Zhu, W.H., 2013. Scale-dependent rates of uranyl surface complexation reaction in sediments. Geochim. Cosmochim. Acta 105, 326-341. 
Liu, C., Zachara, J.M., 2001. Uncertainties of Monod kinetic parameters nonlinearly estimated from batch experiments. Environ. Sci. Technol. 35, 133-141.

Lu, H.J., Chandran, K., 2010. Factors promoting emissions of nitrous oxide and nitric oxide from denitrifying sequencing batch reactors operated with methanol and ethanol as electron donors. Biotechnol. Bioeng. 106, 390-398.

Mastrocicco M, Colombani N, Salemi E, Castaldelli G, 2011. Reactive Modeling of Denitrification in Soils with Natural and Depleted Organic Matter. Water Air Soil Pollut. 222:205-215.

Matějů V, Čižinská S, Krejčí J, Janoch T, 1992. Biological Water Denitrification - a Review. Enzyme Microb. Technol. 14:170-183.

McCarty, P.L., Beck, L., St. Amant, P., 1969. Biological denitrification of wastewaters by addition of organic materials, Proceedings of the 24th annual Purdue Industrial Waste Conference, 1271-1285.

Meyer, C., Papoutsakis, E., 1989. Increased levels of ATP and NADH are associated with increased solvent production in continuous cultures of Clostridium acetobutylicum. Appl. Microbiol. Biotechnol. 30, $450-459$.

Nannipieri, P., Johnson, R.L., Paul, E.A., 1978. Criteria for measurement of microbial growth and activity in soil. Soil Biol. Biochem. 10, 223-229.

Ni B.J., Ruscalleda M, Pellicer-Nàcher C, Smets BF, 2011. Modeling nitrous oxide production during biological nitrogen removal via nitrification and denitrification: Extensions to the general ASM models. Environ. Sci. Technol. 45:7768-7776.

Ni, B.J., Ye, L., Law, Y.Y., Byers, C., Yuan, Z.G., 2013. Mathematical modeling of nitrous oxide $\left(\mathrm{N}_{2} \mathrm{O}\right)$ emissions from full-scale wastewater treatment plants. Environ. Sci. Technol. 47, 7795-7803.

Pan, Y.T., Ye, L., Ni, B.J., Yuan, Z.G., 2012. Effect of $\mathrm{pH}$ on $\mathrm{N}_{2} \mathrm{O}$ reduction and accumulation during denitrification by methanol utilizing denitrifiers. Water Res. 46, 4832-4840.

Pan, Y.T., Ni, B.J., Yuan, Z.G., 2013. Modeling electron competition among nitrogen oxides reduction and $\mathrm{N}_{2} \mathrm{O}$ accumulation in denitrification. Environ. Sci. Technol. 47, 11083-11091.

Percak-Dennett, E.M., Roden, E.E., 2014. Geochemical and microbiological responses to oxidant introduction into reduced subsurface sediment from the Hanford 300 Area, Washington. Environ. Sci. Technol. 48, 9197-9204. 
Peretyazhko, T.S., Zachara, J.M., Kukkadapu, R.K., Heald, S.M., Kutnyakov, I.V., Resch, C.T., Arey, B.W., Wang, C.M., Kovarik, L., Phillips, J.L., Moore, D.A., 2012. Pertechnetate $\left(\mathrm{TcO}_{4}{ }^{-}\right)$reduction by reactive ferrous iron forms in naturally anoxic, redox transition zone sediments from the Hanford Site, USA. Geochim. Cosmochim. Acta 92:48-66.

Pulou, J., Tournebize, J., Chaumont, C., Haury, J., Laverman, A.M., 2012. Carbon availability limits potential denitrification in watercress farm sediment. Ecol. Eng. 49, 212-220.

Rassamee, V., Sattayatewa, C., Pagilla, K., Chandran, K., 2011. Effect of oxic and anoxic conditions on nitrous oxide emissions from nitrification and denitrification processes. Biotechnol. Bioeng. 108, 2036-2045.

Richardson, D., Felgate, H., Watmough, N., Thomson, A., Baggs, E., 2009. Mitigating release of the potent greenhouse gas $\mathrm{N}_{2} \mathrm{O}$ from the nitrogen cycle - could enzymic regulation hold the key? Trends. Biotechnol. 27, 388-397.

Riley, R.G., Zachara, J.M., 1992. Chemical contaminants on DOE lands and selection of contaminant mixtures for subsurface science research. U.S. Department of Energy, Washington, DC.

Rittmann, B.E., McCarty, P.L., 2001. Environmental biotechnology: Principles and applications. McGrawHill Education, New York.

Rivett, M.O., Buss, S.R., Morgan, P., Smith, J.W.N., Bemment, C.D., 2008. Nitrate attenuation in groundwater: A review of biogeochemical controlling processes. Water Res. 42, 4215-4232.

Robertson, W.D., Russell, B.M., Cherry, J.A., 1996. Attenuation of nitrate in aquitard sediments of southern Ontario. J. Hydrol. 180, 267-281.

Ronen, D., Magaritz, M., Almon, E., 1988. Contaminated aquifers are a forgotten component of the global $\mathrm{N}_{2} \mathrm{O}$ budget. Nature 335, 57-59.

Seitzinger, S., Harrison, J.A., Bohlke, J.K., Bouwman, A.F., Lowrance, R., Peterson, B., Tobias, C., Van Drecht, G., 2006. Denitrification across landscapes and waterscapes: A synthesis. Ecol. Appl. 16, 2064-2090.

Small, G.E., Cotner, J.B., Finlay, J.C., Stark, R.A., Sterner, R.W., 2014. Nitrogen transformations at the sediment-water interface across redox gradients in the Laurentian Great Lakes. Hydrobiologia 731, 95108. 
Stanley, P.E., 1989. A review of bioluminescent ATP techniques in rapid microbiology. J. Bioluminescence Chemiluminescence 4, 375-380.

Streuli, C.A., Averell, P.R., 1970. Analytical chemistry of nitrogen and its compounds. John Wiley \& Sons Inc, New York.

U.S. EPA, 1993. Process design manual: Nitrogen control. Cincinnati, Ohio.

Vaclavkova, S., Jorgensen, C.J., Jacobsen, O.S., Aamand, J., Elberling, B., 2014. The importance of microbial iron sulfide oxidation for nitrate depletion in anoxic danish sediments. Aquat. Geochem. 20, 419-435.

Van Trump, J.I., Wrighton, K.C., Thrash, J.C., Weber, K.A., Andersen, G.L., Coates, J.D., 2011. Humic acid-oxidizing, nitrate-reducing bacteria in agricultural soils. mBio 2.

Wang, S., Jaffe, P.R., Li, G., Wang, S.W., Rabitz, H.A., 2003. Simulating bioremediation of uraniumcontaminated aquifers; uncertainty assessment of model parameters. J. Contamin. Hydrol. 64, 283-307.

Ward, B.B., 2013. How nitrogen is lost. Science 341, 352-353.

Weymann, D., Geistlinger, H., Well, R., von der Heide, C., Flessa, H., 2010. Kinetics of $\mathrm{N}_{2} \mathrm{O}$ production and reduction in a nitrate-contaminated aquifer inferred from laboratory incubation experiments. Biogeosciences 7, 1953-1972.

Zhang, J., Yu, Y., Zhu, T., Cai, Z., 2014. The mechanisms governing low denitrification capacity and high nitrogen oxide gas emissions in subtropical forest soils in China. J. Geophys. Res.-Biogeosci. 119, $1670-1683$.

Zhang, Y.C., Slomp, C.P., Broers, H.P., Passier, H.F., Van Cappellen, P., 2009. Denitrification coupled to pyrite oxidation and changes in groundwater quality in a shallow sandy aquifer. Geochim. Cosmochim. Acta 73, 6716-6726.

Zumft, W.G., 1997. Cell biology and molecular basis of denitrification. Microbiol. Mol. Biol. Rev. 61, 533616. 


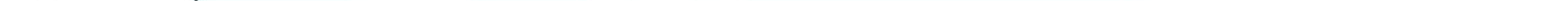

